\title{
Literature Views on Second Language Acquisition-The Ways of Incorporating Interaction and Participation
}

\author{
XU Xiao-fei, ZHU Ping \\ Nanhu College, Jiaxing University, Jiaxing, China
}

\begin{abstract}
Most current theories of second language acquisition and current views on methods and approaches to teaching English as a second language place a high value on student participation and interaction in the language classroom. This interaction may be between teacher and student and/or student and student. Despite this, in many English classrooms around the world, students have very few opportunities to interact in the second language. In this paper, using the literature on second language acquisition research and methodology to prepare a case which highlights why teachers and course designers should find ways to incorporate second language interaction and student participation in their language classes despite the practical difficulties they may face.
\end{abstract}

Keywords: second language acquisition, participation, interaction

\section{Introduction}

An important practical strategy to enhance second language acquisition is to incorporate interaction in the classroom. Interaction can occur between student and a student, or between the teacher and a student, and is likely to increase not only opportunities for the students to receive comprehensible input but also encourage their effective output of the language to achieve communication (Brown, 2007). Whilst there are a number of theories which favor student participation and interaction, there are some practical limitations which teachers also need to overcome.

\section{The Literature on Second Language Acquisition}

This section will discuss interaction in second language acquisition by Krashen's (1982) Input Hypothesis and Swain’s (1985) Output Hypothesis, and also about how Long (1996) has used input and output as necessary aspects of interaction.

Long (1996) devised the Interaction Hypothesis, which is derived from a social constructivist context in which conversational adjustments made during the negotiation of meaning create comprehensible input and maximize learners' opportunities for second language acquisition. Long's theory was a development of Krashen's Input Hypothesis, which states that opportunities for second language acquisition are maximized when learners are exposed to language which is just a little beyond their current level of competence, therefore, if

XU Xiao-fei, assistant lecturer, master, Department of Humanities, Nanhu College, Jiaxing University. ZHU Ping, lecturer, master, Department of Humanities, Nanhu College, Jiaxing University. 
students want to learn a second language, they should aim for Comprehensible Input $i+1$, through listening to oral messages that interlocutors direct to them and via reading written texts that sound them (Ortega, 2009). Swain (1985) argued that the role of comprehensible input on the development in particular of grammatical competence has been overstated, and that the role of comprehensible output is also significant. Hence, Long (1996) argued that tasks involving interaction and negotiation provide more comprehensible input and the interlocutor should modify their speech to negotiate for meaning with each other, known as the input in order to assist in communication to the native speakers to facilitate learning a second language. The teacher is not the only source of input in the classroom. Students also receive input from other learners. The interaction among the students is vital in oral activities, such as situation dialogue, role play, conversation, information-gap, and debate. Students in such activities have the chances to negotiate meaning with each other. Student to student interaction can enhance students' abilities to work collaboratively and foster positive attitudes toward English learning (Johnson, 2000). Also, the teacher interacts with students by simplifying their input and makes clarification checks to help the students to understand the input. A question such as, “does that make sense?” will encourage the students to be more active and interact with the teacher in order to increase their understanding of the teacher's input. The relationship between input and output is complementary, rather than alternative.

\section{Methodologies}

The benefits of student interaction and participation are paramount when learning a second language (Brown, 2007). It helps to engage the student's mind and it can offer a good learning environment. Van Lier (1996) likes to use social interaction in the classroom to promote autonomy and increase awareness to achieve what Vygotsky (1978) argues as approaching the "zone of proximal development". That is to say, during the learning process, a child needs a "zone" or space in which he can interact with others who are more skilled or proficient in an activity than the child is. Applied to language learning, the concept of a zone of proximal development would suggest that through interacting with the teacher and with other students in the classroom, learners can attain a higher level of learning intensity than if they simply sit and listen to the teacher. Student participation should therefore be encouraged, irrespective of the ability or age of the learners.

In order to create maximum opportunities of interaction in the classroom, Ellis (2005) suggests incorporating small group work into a lesson, because acquisition of rich discourse is more likely to occur when students interact among themselves. According to Lightbown and Spada (2006), group and pair work offer learners a lot of opportunities to practice in conversational interactions, thus leading to increased fluency and the ability to manage conversations in second language. Moreover, Richards and Lockhart (1996) state group work reduces the teacher's control over the class and increases the amount of student interaction.

Interaction also encompasses opportunities for feedback as outlined by Gass and Selinker (2007). According to Long (1996), corrective feedback is effective in second language improvement in that students can perceive the differences between output and input by means of a negotiation of meaning. Also, Ellis (2008) claims that interaction provides learners with opportunities to receive corrective feedback, and through this process, language acquisition takes place. Ellis (2008) argues that learners need to negotiate meaning during conversation when communication problems occur, which lead to the use of various negotiation strategies, such as request for clarification, confirmation check, recast and repetition. Also, the student should be encouraged to 
confirm, such as asking the teacher to repeat the phrase so it becomes a two-way feedback loop (Mackey, 2007).

\section{Practical Difficulties}

Despite the fact that interaction and student participation are crucial for second language learning as argued in the previous section, there are some practical difficulties to implement interaction in language classroom.

One of the main difficulties to overcome with teacher interaction is student reticence (Lee \& $\mathrm{Ng}, 2009$ ). Student reticence is defined as the unwillingness to participate, either due to shyness, introvert personality, or fear of speaking out. Lee and Ng (2009) discovered this was most noticeable in students of Asian origin. Liu and Littlewood (1997) also shared the same findings with Lee and Ng (2009) that students in East Asia demonstrated reluctance to participate in the classroom. What is more, students from China tend to be shy and they may feel that publicly displaying one's knowledge in this way would be seen by their classmates as showing off. In our experience, in China, students are taught to be obedient and show respect to the teachers by sitting quietly and writing down what the teachers are saying and memorizing it after class. Hence, students might avoid answering questions because of the educational and cultural influence. Most students prefer to remain silent, and keep answers to themselves. This all leads to students adopting a passive attitude towards classroom interaction, and being reluctant to participate in speaking activities.

Other practical difficulties to implement communicative language teaching (CLT) classrooms are the external causes. Orafi and Borg (2009) claim that a new communicative English language curriculum has not been successfully implemented in Libya because of teachers' beliefs, unsupportive contextual factors toward the changes and also a mismatch between the exams and the curriculum objectives. Therefore, teachers have difficulties implementing CLT. The same difficulties have been experienced in China when applying CLT; large class sizes, and grammar-based tests, create many obstacles to communicative teaching (Liao, 2004).

\section{Solutions}

Even though student reticence is a common problem in the classroom, the benefits of student participation are greater. Moreover, student reticence can be overcome through the teacher adopting an appropriate interaction strategy. Lee and Ng (2009) identify three types of interaction strategies, which are teacher fronted, facilitator orientated, and learner orientated. Lee and Ng's findings show that a facilitator orientated strategy is most effective with students who are not willing to participate. A facilitator orientated strategy involves setting up a topic, using referential questions, reformulation, elaboration, comment, repetition, backchannels, giving content focused feedback and longer wait time (Lee \& Ng, 2009). Moreover, it can make the teacher-controlled interaction enable learners to initiate speaking resulting in free flowing student-student interaction. When learners have interaction difficulties, strategies such as reformulation and elaboration can be used to develop learners' confidence in using English to communicate among themselves. This strategy enables the teacher to develop more authentic dialogues with the students and offers more freedom than the IRF pattern exhibited with the teacher fronted strategy (Yashima, 2002).

Despite its limitations, to some extent, IRF pattern also helps English teachers adopt an interaction strategy, especially for the inexperienced teachers. Taking our context in a Chinese college, in our view, the English 
classroom interaction should employ an IRF pattern to help students overcome reticence. According to IRF pattern, the letter "I" represents an initiating move, such as a question posed by the teacher. " $\mathrm{R}$ " is the response from the class, usually from an individual student, and " $\mathrm{F}$ " is the follow-up feedback or comment by the teacher. Classroom interaction depends on the meaning negotiated and understood through exchanges of discourse between the teacher and the students. Not all utterances are counted as interaction. Interaction exists when the teacher or a student initiates conversation, the students respond, and then teacher gives a follow-up response. Richard Cullen (1998, p. 179) provides an example.

T: What's the boy doing? (I)

$\mathrm{S}$ : He's climbing a tree. (R)

T: That's right. He is climbing a tree. (F)

Liu and Littlewood's (1997) discovered that students preferred to work in pairs or groups, when engaging in language discussion. Harmer (2007) argues that pair work and group work will provoke the quieter students to join in discussion. Scrivener (2011) also points out that it is crucial for teachers to use pair work or group work to avoid students' anxiety, develop their confidence, and produce more negotiation of meaning (Hedge, 2000).

The theories presented thus far can propose that interaction plays an important role in CLT. According to Brown (2007), in the era of CLT, interaction is the heart of communication; it is what communication is all about. However, there are many practical difficulties to implement CLT in language teaching classrooms. Harmer (2007) suggests that to deal with large class size, pair work and group work should be used to maximize the students' participation. Hedge (2000) suggests that role-plays simulate the real world and learners might be encouraged to speak more freely by acting out the roles with a large number of participants.

\section{Conclusion}

To conclude, there are many benefits in using interaction and student participation to enhance second language learning. Long's Interaction Hypothesis asserts that real communication takes place when people are able to interact and negotiate meaning with each other. Gass and Selinker also favor the use of classroom interaction and highlight the importance of providing explicit and implicit feedback to the students. However, in practice, it can be challenging to increase student participation due to student reticence and some external factors. Yet, there are many interaction strategies which teachers can employ to increase student participation in the classroom. The main notion is that teachers need to adopt a flexible approach and facilitator orientated approach, to increase student confidence in their ability to interact and participate actively in their learning.

\section{References}

Brown, H. D. (2007). Principles of language learning and teaching (5th ed.). White Plains, NY: Pearson Longman. Cullen, R. (1998). Teacher talk and the classroom context. ELT Journal, 52(3), 179-87.

Ellis, R. (2005). Principles of instructed language learning. System, 33, 209-224.

Ellis, R. (2008). The study of second language acquisition (2nd ed.). Oxford: Oxford University Press.

Gass, S., \& Selinker, L. (2007). Second language acquisition: An introductory course. London: Lawrence Erlbaum Associates. Harmer, J. (2007). How to teach English. Essex: Pearson Education Limited.

Hedge, C. (2000). Teaching and learning in the language classroom. Oxford: Oxford University Press.

Johnson, K. E. (2000). Understanding communication in second language classrooms. Cambridge: Cambridge University Press. Krashen, S. (1982). Principles and practice in second language acquisition. Oxford: Pergamon Press. 
Lee, W., \& Ng, S. (2009). Reducing student reticence through teacher interaction strategy. ELT Journal, 64(3), 302-313.

Liao, X. Q. (2004). The need for communicative language teaching in China. ELT Journal, 58(3), 270-273.

Lightbown, P. M., \& Spada, N. (2006). How languages are learned (3rd ed.). Oxford: Oxford University Press.

Liu, N., \& Littlewood, W. (1997). Why do many students appear reluctant to participate in classroom learning discourse?. System, 25(3), 371-384.

Long, M. (1996). The role of the linguistic environment in second language acquisition. In W. Ritchie \& T. Bhatia (Eds.), Handbook of second language acquisition (pp. 413-468). San Diego: Academic Press.

Mackey, A. (2007). Conversational interaction in second language acquisition. Oxford: Oxford University Press.

Orafi, S., \& Borg, S. (2009). Intentions and realities in implementing communicative curriculum reform. System, 37(2), $243-253$.

Ortega, L. (2009). Understanding second language acquisition. London: Hodder Education.

Richards, J. C., \& Lockhart, C. (1996). Reflective teaching in second language classroom. Cambridge: Cambridge University Press.

Scrivener, J. (2011). Learning teaching (3rd ed). Oxford: Macmillan Education.

Swain, M. (1985). Communicative competence: Some roles of comprehensible input and comprehensible output in its development. In S. M. Gass \& C. G. Madden (Eds.), Input in second language acquisition (pp. 235-256). Rowley, MA: Newbury House.

Van Lier, L. (1996). Interaction in the language curriculum: Awareness, autonomy, and authenticity. London: Longman.

Vygotsky, L. (1978). Mind in society: The development of higher psychological processes. Cambridge, MA: Harvard University Press.

Yashima, T. (2002). Willingness to communicate in a second language: The Japanese EFL context. The Modern Language Journal, 86(1), 54-64. 